\title{
PERBANDINGAN METODE ISOLASI DNA PADA PRODUK PERIKANAN SEGAR DAN OLAHAN
}

\author{
Aninditya Artina Setiaputri ${ }^{1 *}$, Giri Rohmad Barokah ${ }^{1,2}$, Muh.Alsere Bardian Sahaba ${ }^{1}$, \\ Rahma Dini Arbajayanti ${ }^{1}$, Nadia Fabella ${ }^{1}$, Rizsa Mustika Pertiwi ${ }^{1}$, Mala Nurilmala ${ }^{1}$, \\ Roni Nugraha ${ }^{1}$, Asadatun Abdullah ${ }^{1}$ \\ ${ }^{1}$ Departemen Teknologi Hasil Perairan, Fakultas Perikanan dan Ilmu Kelautan, IPB University \\ ${ }^{2}$ Balai Besar Riset Pengolahan Produk dan Bioteknologi Kelautan dan Perikanan \\ Diterima: 27 Agustus 2020/Disetujui: 06 November 2020 \\ Korespondensi: mnurilmala@apps.ipb.ac.id
}

Cara sitasi: Setiaputri AA, Barokah GR, Sahaba MAB, Arbajayanti RD, Fabella N, Pertiwi RM, Nurilmala M, Nugraha R, Abdullah A. 2020. Perbandingan metode isolasi DNA pada produk perikanan segar dan olahan. Jurnal Pengolahan Hasil Perikanan Indonesia. 23(3): 447-458.

\begin{abstract}
Abstrak
Produk perikanan menjadi salah satu komoditas pangan penting dalam dunia perdagangan, akan tetapi perkembangan tersebut diikuti dengan meningkatnya kasus pemalsuan produk perikanan yang dapat merugikan konsumen. Oleh karena itu diperlukan metode untuk mengidentifikasi secara spesifik spesies produk perikanan. Salah satu metode seafood authentication yang telah dikembangkan adalah metode berbasis DNA.. Penelitian ini bertujuan untuk menentukan konsentrasi dan kemurnian DNA berdasarkan beberapa metode isolasi pada produk perikanan segar dan olahan. Metode isolasi DNA yang digunakan pada penelitian ini adalah metode konvensional cetyl trimethylammonium bromide (CTAB) dan beberapa kit komersial (DNAzol, TianGen, Qiagen, dan Fasmac). Konsentrasi dan kemurnian DNA ditentukan berdasarkan spektrofotometri nanodrop, serta visualisasi elektroforegram hasil elektroforesis. Hasil isolasi DNA menunjukkan bahwa konsentrasi DNA produk perikanan segar lebih tinggi dibandingkan dengan konsentrasi isolat DNA pada produk perikanan olahan. Isolat DNA dengan metode isolasi CTAB memiliki tingkat kemurnian DNA yang lebih tinggi (1.60-2.00) jika dibandingkan isolat DNA meggunakan kit komersial pada semua sampel. Metode kit komersial menawarkan prosedur yang lebih sederhana, menghindari penggunaan reagen berbahaya, dan meminimalisir kemungkinan adanya kontaminan lingkungan.
\end{abstract}

Kata kunci: CTAB, identifikasi, isolasi DNA, pemurnian DNA

\section{Comparison of DNA Isolation Methods for Fresh and Processed Seafood}

\begin{abstract}
Seafood product is an important commodity in the global trade market, however, seafood fraud has been increasingly reported. Therefore, a method to specifically identify species of seafood products is needed. DNA methods gain many interests for detection of seafood fraud due to its robustness. This study was aimed to determine the effectiveness of several methods for isolation of DNA from fresh and processed seafood. The DNA isolation methods used in this study were the CTAB DNAzol, TianGen, Qiagen, and Fasmac.. DNA concentration and purity were determinedusing nanodrop spectrofotometry and electrophoresis. DNA isolation showed that the DNA concentration of fresh seafood products was higher than the processed seafood products. DNA isolation using CTAB method have higher levels of DNA purity (1.60-2.00) than using commercial kits in all samples. The commercial kits offer a simple procedure and minimize the possibility of environmental contaminants.
\end{abstract}

Keywords: CTAB, DNA isolation, DNA purification, identification. 


\section{PENDAHULUAN}

Produk perikanan merupakan komoditas pangan yang memiliki kandungan protein, asam lemak omega-3 dan mikronutrien esensial yang sangat penting bagi kesehatan (Dhaneesh et al. 2012; Nichols et al. 2014). Kesadaran masyarakat yang meningkat akan manfaat konsumsi produk perikanan bagi kesehatan berbanding lurus dengan meningkatnya konsumsi ikan secara global (Khaksar et al. 2015). Hal tersebut membuat produk perikanan menjadi salah satu komoditas pangan penting dalam dunia perdagangan (Asche et al. 2015), akan tetapi meningkatnya perdagangan produk perikanan tersebut juga meningkatkan kasus pemalsuan produk perikanan yang dilaporkan ditemukan di pasaran (Willete et al. 2017). Kasus pemalsuan tersebut memiliki dampak negatif baik secara kesehatan maupun secara ekonomi bagi konsumen (Naaum et al. 2016; Carlvalho et al. 2015). Hal tersebut mendorong dilakukannya identifikasi spesies ikan untuk memastikan keamanan pangan produk perikanan dari kasus pemalsuan produk perikanan.

Identifikasi spesies ikan secara tradisional dapat dilakukan dengan melihat karakteristik morfologi pada ikan misalnya kepala, gigi, kulit, sirip, warna dan bentuk tubuh ikan (Millana et al. 2004). Beberapa proses pengolahan di antaranya pemanasan, pengalengan, pembekuan dan proses pengolahan diversifikasi produk lainnya menyulitkan proses indentifikasi produk perikanan dilakukan melakukan pendekatan morfologi (Zhang dan Hanner 2012). Oleh karena itu, diperlukan metode identifikasi spesifik spesies ikan yang lebih akurat dibandingkan dengan identifikasi spesies ikan secara morfologis. Salah satu teknik identifikasi spesies ikan yang telah dikembangkan adalah indentifikasi spesifik spesies ikan berbasis DNA (Armani et al. 2015; Lamendin et al. 2015; Wong dan Hanner 2008). Kelebihan identifikasi spesies ikan berbasis DNA adalah lebih stabil terhadap beberapa proses pengolahan seperti pemanasan dan pembekuan serta memiliki keakuratan yang lebih tinggi dibandingkan indentifikasi spesies ikan secara morfologi (Dipinto et al. 2015; Zhang dan Hanner 2012). Pendekatan identifikasi spesies ikan berbasis DNA yang telah dikembangkan adalah dengan mengamplifikasi segmen DNA dari sitokrom b dan menentukan sekuensnya serta amplifikasi gen cytochrome $c$ oxidase I (COI) (Mackie et al. 1999). Gen DNA cytochrome oxidase subunit I (COI) memiliki kemampuan untuk berfungsi sebagai kode batang pada hewan menggunakan fragmen 650 pasangan basa yang disebut sebagai DNA fulllength (Hebert et al. 2003). Beberapa metode pengolahan dan pengawetan yang digunakan pada produk makanan laut tidak kondusif untuk DNA full-length. Hal tersebut disebabkan oleh adanya penambahan zat aditif, pengawet, dan rasa yang dapat memengaruhi kualitas dan kuantitas DNA yang diekstraksi (Civera 2003; Rasmussen-Hellberg et al. 2011; Shokralla et al. 2011). Pendekatan alternatifnya adalah pendekatan mini-barcoding yang memfokuskan analisis pada fragmen DNA yang lebih pendek (100200 bp) dalam kode batang full-length telah terbukti efektif dalam memperoleh informasi urutan DNA dari spesimen yang mengandung DNA yang terdegradasi (Hajibabaei et al. 2006; Meusnier et al. 2008). Penelusuran label pada produk olahan hasil perairan berbasis DNA telah banyak dilakukan, di antaranya berbasis COI pada produk surimi (Abdullah et al. 2019a), mini COI pada produk ikan sidat (Abdullah et al. 2018), berbasis cytochrome $b$ COI pada ikan tenggiri (Maulid et al. 2016), menggunakan mini barcode DNA pada produk ikan layur (Abdullah et al. 2019b) serta tuna dan produk olahan tuna berbasis DNA barcoding (Wulansari et al. 2015).

Tahapan awal yang diperlukan untuk mengindentifikasi spesies ikan secara molekuler adalah isolasi DNA (Cawthorn et al. 2012). Keberhasilan proses isolasi DNA ditentukan oleh kuantitas dan kualitas kemurnian DNA yang dihasilkan (Chowdhury et al. 2016; $\mathrm{Hu}$ et al. 2015). Beberapa teknik isolasi DNA telah dikembangkan baik secara konvensional maupun menggunakan kit isolasi DNA yang sudah dikembangkan secara komersial (Bohme et al. 2019). Kelebihan dan kekurangan dari metode isolasi DNA untuk mengindentifikasi spesies ikan baik pada produk segar dan olahan dengan metode konvensional dan menggunakan kit komersial belum dijelaskan secara jelas. Penelitian ini 
bertujuan untuk menentukan efektivitas beberapa metode dalam mengisolasi DNA dari produk perikanan segar dan olahan. Hasil penelitian diharapkan dapat dijadikan dasar rekomendasi dalam pemilihan kit isolasi DNA yang akan digunakan untuk melakukan identifikasi spesies berbasis DNA khususnya pada produk perikanan.

\section{BAHAN DAN METODE Bahan dan Alat}

Sampel yang digunakan dalam penelitian ini adalah ikan cakalang (Katsuwonus pelamis) dari perairan Binuangeun Banten, ikan nila (Oreochromis niloticus) dari kolam budi daya IPB, steik tuna, crab stick dan bakso ikan yang diperoleh dari pasar swalayan di daerah Bogor Jawa Barat. Bahan kimia yang digunakan pada penelitian ini adalah akuades, fenol (Merck), kloroform (Merck), isoamilalkohol (Merck), larutan CTAB 2\%, proteinase K (Sigma Aldrich), buffer TE (Sigma Aldrich), kit isolasi DNA (QIAGEN DNeasy Blood \& Tissue, QIAGEN DNeasy Food Mericon, TIANamp Genomic DNA Kit (TianGen), DNAzol ${ }^{\circ}$ Genomic DNA Isolation Reagent, GenCheck ${ }^{\bullet}$ DNA Extraction Reagent (FASMAC), gel agarosa, cybergreen, loading dye, bufer TBE.

Alat yang digunakan pada penelitian ini meliputi pipet tips RC-10/20-L dan RC250/20-C (Mettler Toledo, Bekasi Indonesia), 4 micropipette 1-10 $\mu \mathrm{L}$, dan 20-200 $\mu \mathrm{L}$ (ThermoFisher Scientific, Vantaa, Finlandia), vortex (V1-Plus, Biosan, Warren, AS), spin down (Corning, New York, AS), mikrosentrifugasi (Centurion Scientific 2041, Libertyville, AS), microwave (Sharp, Osaka, Jepang), timbangan digital (PHW 254, $\mathrm{ADAM}^{\circ}$, Inggris), spektrofotometri nanodrop (Implan NP-80), UV-Transilluminator (UVitec, Cambridge, Inggris) dan elektroforesis horizontal (HU6, SCIE-PLAS, Cambridge, Inggris).

\section{Metode Penelitian \\ Preparasi sampel}

Sampel terdiri dari ikan cakalang, ikan nila, produk steik tuna, bakso ikan dan crab stick dipreparasi. Kelima sampel tersebut dihaluskan menggunakan mortar, kemudian ditimbang sebanyak 10 g. Sampel yang telah siap disimpan pada suhu chilling untuk menjaga kualitas sampel untuk selanjutnya diisolasi.

\section{Isolasi DNA sampel dengan metode CTAB}

Isolasi DNA menggunakan metode CTAB mengacu pada metode Hseih et al. (2005) menggunakan larutan CTAB 2\% yang memiliki komposisi $100 \mathrm{~mL}$ Tris $\mathrm{HCl}$

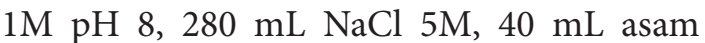
etilenadiaminatetraasetat (EDTA) 0,5 M, $20 \mathrm{~g}$ $\mathrm{CTAB}$, dan $1 \mathrm{~L}$ akuades. Isolasi diawali dengan penimbanganmasing-masingsampelsebanyak 0,1-0,5 g. Sampel ditambah $500 \mu \mathrm{L}$ larutan CTAB $2 \%$ dan $14 \mu \mathrm{L}$ proteinase $\mathrm{K}$, selanjutnya dilakukan inkubasi pada suhu $55^{\circ} \mathrm{C}$ selama 2 jam. Cairan kemudian disentrifugasi pada kecepatan $13.000 \mathrm{~g}$ selama 10 menit. Endapan yang diperoleh ditambahkan larutan PCI (fenol, kloroform, isomilalkohol) sebanyak $500 \mu \mathrm{L}$. Campuran tersebut dihomogenisasi dan disentrifugasi $13.000 \mathrm{~g}$ selama 5 menit. Langkah selanjutnya natan dibuang dan ditambahkan $400 \mu \mathrm{L}$ larutan CIA (kloroform dan isoamil alkohol). Campuran tersebut dihomogenisasi dan disentrifugasi dengan kecepatan $13.000 \mathrm{~g}$ selama 5 menit, kemudian natan dibuang dan ditambahkan $400 \mu \mathrm{L}$ larutan CIA. Campuran tersebut kembali dihomogenisasi dan disentrifugasi $13.000 \mathrm{~g}$ selama 5 menit. Supernatan sebanyak $1,5 \mathrm{ml}$ dipindahkan ke microtube baru. Campuran tersebut ditambah $600 \mu \mathrm{L}$ isopropanol lalu dipresipitasi semalam pada suhu $-4^{\circ} \mathrm{C}$ dan disentrifugasi $13.000 \mathrm{~g}$ selama 10 menit. Larutan isopropanol dibuang dan ditambah $500 \mu \mathrm{L}$ etanol 70\% kemudian disentrifugasi $13.000 \mathrm{~g}$ selama 10 menit. Supernatan yang dihasilkan dibuang. Pelet yang diperoleh dikeringkan selama $1 \mathrm{jam}$, kemudian ditambahkan 100 $\mu \mathrm{L}$ buffer TE. Pelet DNA yang telah larut kemudian disimpan sebagai DNA stok pada suhu $-20^{\circ} \mathrm{C}$.

\section{Isolasi DNA sampel dengan kit isolasi DNAzo/@ Genomic DNA Isolation Reagent}

Proses isolasi DNA menggunakan kit komersial DNAzol ${ }^{\circ}$ Genomic DNA Isolation Reagent pada ikan segar dan produk olahan dimulai dengan menimbang $25 \mathrm{mg}$ 
sampel kemudian dipindahkan ke dalam microtube. Sampel tersebut ditambahkan 1 $\mathrm{mL}$ DNAzol genomic. Suspensi selanjutnya diaduk sebanyak $10 \times$ di dalam microtube dan disimpan pada suhu ruang selama 10 menit. Sampel disentrifugasi pada kecepatan $10.000 \mathrm{~g}$ selama 10 menit. Supernatan yang diperoleh lalu dipindahkan ke dalam microtube baru. Supernatan ditambahkan $0,5 \mathrm{~mL}$ etanol $100 \%$, lalu diaduk dengan cara microtube dibolak-balik sebanyak 8 kali, kemudian disimpan pada suhu ruang selama 3 menit. Apabila terbentuk serabut putih (DNA) maka dilakukan penempelan DNA pada dinding microtube dengan tip, namun apabila tidak terbentuk serabut putih (DNA) maka akan dilakukan sentrifugasi pada kecepatan $5.000 \mathrm{~g}$ selama 5 menit, lalu supernatan dibuang. Campuran DNAzol dan etanol dengan rasio 7:3 ditambahkan sebanyak $1 \mathrm{~mL}$, microtube dibolak-balik sebanyak 6 kali, dan selanjutnya disentrifugasi pada kecepatan $1.000 \mathrm{~g}$ selama 2 menit. Supernatan kembali dibuang. Proses mulai dari penambahan DNAzol dan etanol hingga pembuangan supernatan ini dilakukan sebanyak 2 kali, kemudian DNA dilarutkan pada $300 \mu \mathrm{L} 8 \mathrm{mM}$ $\mathrm{NaOH}$. Isolat DNA yang diperoleh disimpan pada $-20^{\circ} \mathrm{C}$ untuk dianalisis lebih lanjut.

\section{Isolasi DNA sampel dengan kit isolasi TIANamp Genomic DNA Kit (TianGen)}

Isolasi DNA menggunakan kit komersial TIANamp Genomic DNA Kit, TianGen diawali dengan menimbang sampel sebanyak 10 $25 \mathrm{mg}$ diletakkan dalam microtube. Sampel tersebut ditambahkan dengan $200 \mu \mathrm{L}$ bufer GA dan $20 \mu \mathrm{L}$ proteinase-K, kemudian dihomogenisasi dengan vortex dan di-spin down. Sampel kemudian diinkubasi pada suhu $56{ }^{\circ} \mathrm{C}$ selama 2 jam. Sampel kemudian ditambahkan dengan $200 \mu \mathrm{L}$ bufer $\mathrm{GB}$, lalu dihomogenisasi dengan vortex dan di-spin down kemudian diinkubasi kembali pada suhu $70{ }^{\circ} \mathrm{C}$ selama 10 menit. Sampel selanjutnya ditambahkan dengan $200 \mu \mathrm{L}$ etanol (96-100\%), kemudian dihomogenisasi dengan vortex dan di-spin down. Filtrat dipindahkan ke dalam spin column dan disentrifugasi dengan kecepatan $12.000 \mathrm{~g}$ selama 30 detik. Supernatan yang dihasilkan dibuang kemudian ditambahkan $700 \mu \mathrm{L}$ bufer PW dan disentrifugasi dengan kecepatan $12.000 \mathrm{~g}$ selama 30 detik. Supernatan yang dihasilkan dibuang, kemudian ditambahkan $500 \mu \mathrm{L}$ bufer PW dan disentrifugasi dengan kecepatan $12.000 \mathrm{~g}$ selama 30 detik, selanjutnya dilakukan pemindahan kolom ke microtube baru. Cairan tersebut kemudian ditambahkan $100 \mu \mathrm{L}$ bufer TE, lalu diinkubasi pada suhu 15-25 ${ }^{\circ} \mathrm{C}$ selama 2-5 menit dan disentrifugasi $12.000 \mathrm{~g}$ selama 2 menit. Isolat DNA disimpan pada suhu $-20^{\circ} \mathrm{C}$ untuk dianalisis lebih lanjut.

\section{Isolasi DNA sampel dengan kit isolasi Qiagen}

Isolasi dengan kit QIAGEN DNeasy Blood and Tissue untuk produk segar diawali dengan penimbangan sampel sebanyak 0,05 g daging ikan kemudian dimasukkan ke dalam microtube. Sampel ditambahkan $180 \mu \mathrm{L}$ bufer ATL dan $20 \mu \mathrm{L}$ proteinase $\mathrm{K}$, lalu dihomogenisasi dengan vortex. Sampel diinkubasi dalam waterbath selama 8 menit pada suhu $60{ }^{\circ} \mathrm{C}$. Sampel ditambahkan etanol $96 \%$ sebanyak $200 \mu \mathrm{L}$, dihomogenisasi dengan vortex dan disimpan selama 30 menit pada suhu $-20{ }^{\circ} \mathrm{C}$. Sampel dipindahkan ke dalam spin column yang telah ditempatkan pada collection tube sebanyak $2 \mathrm{~mL}$ kemudian disentrifugasi dengan kecepatan $8.000 \mathrm{~g}$ selama 1 menit. Collection tube beserta larutan yang berada di dalamnya dibuang. Spin column ditempatkan pada collection tube baru dan ditambahkan bufer AW1 sebanyak $500 \mu \mathrm{L}$, dilanjutkan sentrifugasi dengan kecepatan $8.000 \mathrm{~g}$ selama 1 menit. Collection tube beserta larutan yang berada di dalamnya dibuang, selanjutnya spin column ditempatkan pada collection tube baru dan ditambahkan $500 \mu \mathrm{L}$ bufer AW2 kemudian disentrifugasi dengan kecepatan 14.000 rpm selama 3 menit. Spin column ditempatkan pada microtube baru dan ditambahkan $100 \mu \mathrm{L}$ bufer AE, inkubasi selama 10 menit pada suhu ruang, kemudian disentrifugasi dengan kecepatan $8.000 g$ selama 1 menit dan diperoleh isolat DNA pada 
bagian bawah tube. Isolat DNA yang diperoleh disimpan pada $-20{ }^{\circ} \mathrm{C}$ untuk dianalisis lebih lanjut.

Isolasiuntukprodukolahan menggunakan kit QIAGEN DNeasy Mericon Food Kit. Sampel sebanyak 0,25 gram diletakkan dalam microtube. Sampel ditambahkan $1 \mathrm{ml}$ bufer food lysis dan 2,5 $\mu \mathrm{L}$ proteinase $\mathrm{K}$. Campuran tersebut dihomogenisasi dengan vortex selama 8 detik. Sampel kemudian diinkubasi pada suhu $60^{\circ} \mathrm{C}$ selama 16 jam dan di-vortex setiap satu jam. Sampel disentrifugasi dengan kecepatan $2.500 \mathrm{~g}$ selama 5 menit. Supernatan diambil sebanyak $700 \mu \mathrm{L}$, dimasukkan ke dalam tube baru dan ditambahkan kloroform sebanyak $500 \mu \mathrm{L}$. Sampel dihomogenisasi menggunakan vortex dan spin down selama 15 detik, kemudian disentrifugasi selama 15 menit dengan kecepatan 14.000 g. Supernatan diambil sebanyak $350 \mu \mathrm{L}$ dan ditambahkan larutan bufer PB sebanyak $350 \mu \mathrm{L}$ pada tube baru kemudian dihomogenisasi dengan vortex. Campuran larutan tersebut dipindahkan ke spin column dalam collection tube dan disentrifugasi dengan kecepatan $17.900 \mathrm{~g}$ selama 1 menit, selanjutnya ditambahkan bufer AW2 sebanyak $500 \mu \mathrm{L}$ dan disentrifugasi kembali dengan kecepatan $17.900 \mathrm{~g}$ selama 1 menit. Cairan pada bagian collection tube dibuang dan collection tube dipasang kembali, kemudian disentrifugasi kembali dengan kecepatan dan waktu yang sama. Tube kemudian dipindahkan ke microtube yang baru, selanjutnya ditambahkan bufer EB sebanyak $150 \mu \mathrm{L}$ dan diinkubasi selama 1 menit pada suhu $25{ }^{\circ} \mathrm{C}$, kemudian disentrifugasi pada kecepatan $17.900 \mathrm{~g}$ selama 1 menit dan diperoleh isolat DNA pada bagian bawah tube. Isolat DNA yang diperoleh disimpan pada $-20^{\circ} \mathrm{C}$ untuk dianalisis lebih lanjut.

\section{Isolasi DNA sampel dengan kit isolasi GenCheck@ DNA Extraction Reagent (FASMAC)}

Isolasi DNA dengan menggunakan kit GenCheck ${ }^{\diamond}$ DNA Extraction Reagent (FASMAC) diawali dengan penimbangan sampel sebanyak $10 \mathrm{~g}$ kemudian dimasukkan ke dalam microtube ukuran 1,5 mL. Sampel dalam microtube ditambahkan $100 \mu \mathrm{L}$ reagen ekstraksi DNA, kemudian dihomogenisasi menggunakan vortex lalu di-spindown agar seluruh sampel mengendap di dasar microtube. Sampel diinkubasi pada suhu $100{ }^{\circ} \mathrm{C}$ selama 10 menit, kemudian didinginkan dalam es selama 1 menit dan disentrifugasi pada $15.000 \mathrm{~g}$ selama 1 menit pada suhu ruang dan diperoleh isolat DNA. Isolat DNA yang diperoleh disimpan pada $-20^{\circ} \mathrm{C}$ untuk dianalisis lebih lanjut.

\section{Elektroforesis isolat DNA}

Elektroforesis isolat DNA sampel dilakukan dengan mengacu pada metode Westermeier (2004). Elektroforesis dilakukan untuk mengamati keberhasilan isolat DNA yang didapatkan dari sampel. Kuat arus yang digunakan $60 \mathrm{~A}$ dengan tegangan 90 volt. Elektroforesis dilakukan selama 30 menit. Media gel yang digunakan yaitu gel agarosa 1,2\%. Agarosa ditimbang sebanyak 0,6 g, kemudian ditambahkan bufer TBE sebanyak $1 \times 50 \mathrm{~mL}$, selanjutnya dipanaskan menggunakan oven pada suhu $100^{\circ} \mathrm{C}$ selama 30 menit. Larutan didiamkan pada suhu ruang selama 15 menit, kemudian dimasukkan ke dalam alat elektroforesis horizontal. Tahapan uji kualitas DNA yaitu, pertama disiapkan larutan cybergreen sebanyak $3 \mu \mathrm{L}$, kemudian ditambahkan loading dye sebanyak $3 \mu \mathrm{L}$ dan isolat DNA sebanyak $3 \mu \mathrm{L}$. Isolat kemudian divisualisasi mengunakan UVtransiluminator.

\section{Konsentrasi dan kemurnian DNA}

Konsentrasi dan kemurnian DNA merupakan tahapan penting bagi rangkaian proses isolasi DNA. Analisis konsentrasi dan kemurnian DNA pada penelitian ini dilakukan dengan mengacu pada metode Chen et al. (2010). Konsentrasi dan kemurnian (rasio absorbansi pada 260/280) dari DNA yang diekstraksi ditentukan menggunakan spektrofotometer nanodrop (Implan NP-80). Bufer lisis yang digunakan pada isolasi DNA diteteskan pada sensor nanodrop sebanyak $1 \mu \mathrm{L}$ lalu dijalankan sebagai blangko, kemudian sensor dibersihkan dan diteteskan isolat DNA sampel sebanyak $1 \mu \mathrm{L}$ lalu dianalisis menggunakan nanodrop (Implan NP-80). 
Tahap tersebut dilakukan pada setiap sampel isolat DNA. Pengukuran konsentrasi DNA dengan nanodrop dilakukan pada panjang gelombang $260 \mathrm{~nm}$, sedangkan protein diukur pada panjang gelombang $280 \mathrm{~nm}$ dengan DNA murni didefinisikan memiliki rasio absorbansi 260/280 berkisar antara 1,6 dan 2,0.

\section{HASIL DAN PEMBAHASAN Elektroforegram Isolat DNA Sampel}

Keberhasilan suatu ekstraksi pemurnian dan kuantitas dari DNA sangat tergantung dari isolasi DNA yang dihasilkan. Isolasi DNA pada sampel perikanan segar dan olahan dapat dilakukan dengan menggunakan metode manual CTAB ataupun kit komersial. Kit komersial yang digunakan yaitu TIANamp genomic DNA kit, DNAzol Genomic DNA Isolation Reagent, GenCheck ${ }^{\circledR}$ DNA Extraction Reagent (FASMAC), dan Qiagen (QIAGEN DNeasy Blood and Tissue yang digunakan untuk sampel segar, dan QIAGEN DNeasy Food Mericon kit yang dikhususkan untuk sampel makanan). Prinsip dari isolasi DNA adalah proses pelisisan pada sel, ekstraksi, dan pengendapan (Maulid dan Nurilmala 2015). Pelisisan merupakan proses lisis atau penghancuran sel menggunakan protease, dilanjutkan dengan ekstraksi yaitu mengeluarkan materi di dalam organel sel dengan menghancurkannya baik secara kimia maupun fisik. Pengendapan merupakan proses pemisahan antara material DNA dengan materi lain pada organel sel melalui perbedaan berat (Abdullah et al. 2019a).

Isolasi DNA pada sampel perikanan segar dan olahan dapat dilakukan dengan menggunakan metode manual CTAB ataupun kit komersial. Kit komersial yang digunakan untuk isolasi DNA terdiri atas 4 kit, yaitu TIANamp genomic DNA kit, DNAzol ${ }^{\circ}$ Genomic DNA Isolation Reagent, GenCheck ${ }^{\otimes}$ DNA Extraction Reagent (FASMAC), dan Qiagen (QIAGEN DNeasy Blood and Tissue yang digunakan untuk sampel segar, dan QIAGEN DNeasy Food Mericon kit yang dikhususkan untuk sampel makanan). Metode CTAB sering digunakan untuk memfasilitasi ekstraksi DNA karena kemampuan bahan kimia tersebut membentuk kompleks dengan DNA (Krishnaswamy et al. 2006), namun diperlukan perlakuan awal sampel, seperti penghilangan lemak, penting dilakukan sebelum ekstraksi DNA (Piskata et al. 2007). Adapun isolasi DNA menggunakan kit komersial lebih aman dari kesalahan pengerjaan yang menimbulkan kontaminasi, namun penelitian pada beberapa spesimen dengan berbagai perlakuan menyatakan tidak semua kit komersial mampu memanen DNA dalam konsentrasi tinggi (Hajibabaei et al. 2005).

Elektroforegram isolat DNA menggunakan metode CTAB menunjukkan hasil pita DNA yang berbentuk noda atau smear pada sampel ikan cakalang, steik tuna dan ikan nila, sedangkan pada sampel produk olahan yaitu bakso ikan dan crabstick tidakterlihat pita DNA ataupun smear. Pita DNA yang tidak terbentuk pada sampel produk olahan yaitu bakso ikan dan crab stick dapat disebabkan karena DNA target telah rusak selama proses pengolahan. Lin et al. (2016) menjelaskan bahwa kualitas dan kuantitas pada isolat DNA produk olahan dipengaruhi oleh proses pengolahan, kualitas DNA yang rendah dipengaruhi oleh adanya penambahan bahan tambahan lain. Dwiyitno et al. (2018) menyatakan bahwa pada metode isolasi klasik rendemen DNA dipengaruhi oleh konsentrasi larutan lisis dan enzim yang digunakan (proteinase $\mathrm{k}$ dan RNase). Smear yang terbentuk pada sampel ikan cakalang, ikan nila dan steik tuna dapat disebabkan telah terjadinya kontaminasi dan masih terbawanya sisa larutan yang digunakan saat proses isolasi DNA. Suparningtyas et al. (2018) menyatakan bahwa smear yang terbentuk pada proses isolasi menunjukkan telah terjadinya degradasi atau fragmentasi DNA genom selama proses isolasi. Lin et al. (2016) menjelaskan bahwa perbedaan dalam hasil dapat dikaitkan baik dengan jenis sampel dan/atau konsentrasi CTAB karena konsentrasi yang tidak tepat dapat membentuk kompleks dengan DNA terhadap lipid, selain itu, DNA dapat berkondensasi dengan $\mathrm{CTAB}$ dalam kompleks yang tidak larut ketika rasio CTAB/DNA lebih dari 1,0. Sisa lipid dan konsentrasi CTAB yang tidak optimal dapat berkontribusi pada hasil DNA yang rendah. Fitriya et al. (2015) menyatakan bahwa metode CTAB memiliki keunggulan 


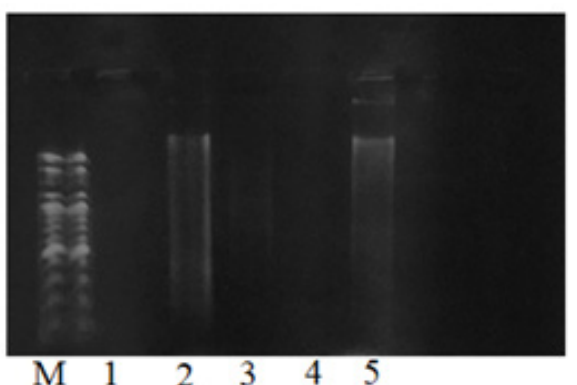

A
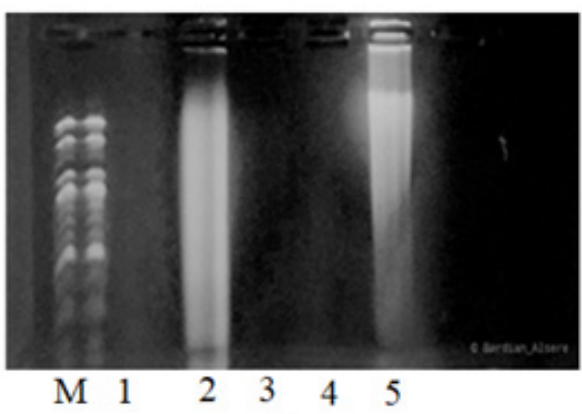

C

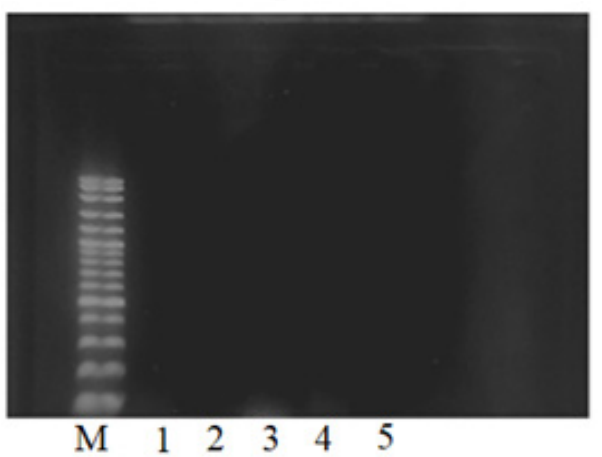

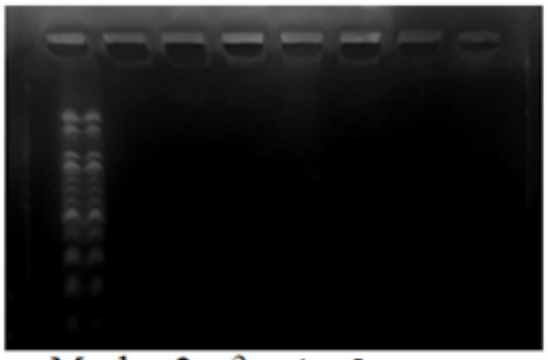

$\begin{array}{llllll}\mathrm{M} & 1 & 2 & 3 & 4 & 5\end{array}$

B

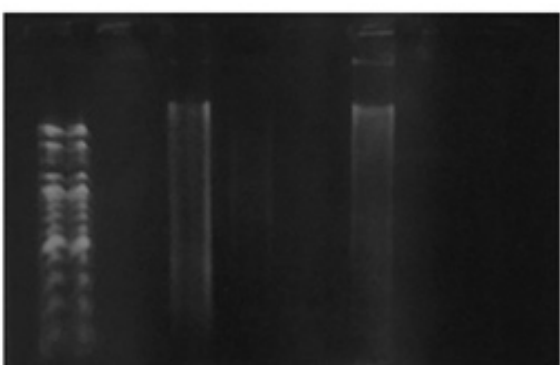

$\begin{array}{llllll}M & 1 & 2 & 3 & 4 & 5\end{array}$

D

E

Figure 1 Gel electrophoresis profile Isolate DNA (A: CTAB method, B: DNAzol method, C: QIAGEN method (QIAGEN DNeasy Blood and Tissue, and QIAGEN DNeasy Food Mericon), D: TianGen method, E : Fasmac method, M: Marker, 1: Crab stick, 2: Skipjack, 3: Tuna Steak, 4: Fishball, 5: Tilapia)

yaitu memiliki kemampuan melisiskan yang kuat dan memudahkan mempresipitasi protein dan debris sel, sehingga dapat menghasilkan konsentrasi DNA yang tinggi. Metode CTAB juga memiliki kekurangan yaitu membutuhkan waktu yang relatif lama dan hasil yang diperoleh tergantung pada jenis sampel yang digunakan.

Hasil isolasi DNA menggunakan kit DNAzol menunjukkan bahwa pada kelima sampel yang dianalisis tidak ditemukan DNA yang terisolasi. Hal ini diduga karena terjadinya kontaminasi mulai dari produk tersebut hingga selama proses isolasi. Menurut
Gardenia dan Koesharyani (2011) DNAzol reagen berada di bawah skala murni, hal ini menunjukkan adanya kontaminasi protein, fenol, garam atau kontaminan lainnya yang diabsorbsi pada panjang gelombang $230 \mathrm{~nm}$. Metode reagen DNAzol mengandung larutan detergen guadinin sebagai bahan pelisis yang menghidrolisis RNA dan mempresipitasi DNA. Larutan tersebut ikut terabsorbsi pada panjang gelombang $230 \mathrm{~nm}$ sehingga nilai rasionya menjadi rendah. Selain itu nilai rasio yang rendah dapat disebabkan oleh adanya zat EDTA, karbohidrat, dan fenol. Pita yang tidak jelas dapat terjadi karena 
kontaminasi terutama urea pada permukaan sumur gel poliakrilamid. Pita yang tidak muncul dapat disebabkan oleh kemungkinan urutan basa nukleotida dari primer tersebut bukan merupakan komplemen dari basa nukleotida pada cetakan DNA target. Hal ini menyebabkan primer-primer tersebut tidak dapat mengamplifikasi fragmen DNA (Hartati et al. 2007).

Elektroforegram isolat DNA menggunakan kit TIANgen dan Qiagen menunjukkan hasil yang tidak jauh berbeda dengan dengan isolat DNA pada metode CTAB 2\% yaitu hanya terbentuk smear pada sampel ikan cakalang, steik tuna, dan ikan nila, namun tidak terdeteksi pada sampel produk olahan. Lin et al. (2018) menyatakan bahwa paparan panas dapat menyebabkan fragmentasi DNA dan adanya perlakuan fisik atau kimia selama proses pemanasan dapat menyebabkan untai DNA pecah secara acak sehingga DNA sulit untuk diisolasi.

Berdasarkan hasil elektrogram isolat DNA menggunakan kit FASMAC dari kelima sampel yang digunakan tidak terlihat adanya pita. Hal ini diduga karena pada proses isolasi tidak dilakukan penambahan proteinase $\mathrm{K}$ dan waktu inkubasi yang dilakukan terlalu cepat sehingga proses lisis yang terjadi tidak sempurna. Wasko et al. (2003) menyatakan bahwa waktu, suhu dan konsentrasi proteinase $\mathrm{K}$ sangat penting untuk isolasi DNA berkualitas tinggi. Suhu kurang dari $42{ }^{\circ} \mathrm{C}$ dan durasi inkubasi kurang dari 10 jam mungkin tidak memisahkan jaringan dengan baik untuk isolasi DNA yang tepat, sedangkan pada penelitian Muhammad et al. (2016) hanya dengan menggunakan $10 \mu \mathrm{L}$ proteinase $\mathrm{K}$ dalam bufer lisis dan menginkubasi jaringan sirip selama 2-3 jam pada $48{ }^{\circ} \mathrm{C}$ dan memperoleh kualitas dan kuantitas DNA yang sangat tinggi.

\section{Konsentrasi dan Kemurnian Isolat DNA}

Isolasi DNA dilakukan dengan tujuan untuk memisahkan DNA dari bahan lain seperti protein, lemak, dan karbohidrat. Isolat DNA yang diperoleh kemudian diukur konsentrasi DNA dan kemurnian DNA menggunakan spektrofotometer nanodrop dengan membandingkan absorbansi asam nukleat pada $\lambda=260 \mathrm{~nm}$ dan protein pada $\lambda=$ $280 \mathrm{~nm}$ (Alaey et al. 2005). Hasil konsentrasi isolasi DNA yang diperoleh dari proses isolasi DNA dengan menggunakan berbagai metode isoasi DNA disajikan pada Table 1.

Nilai konsentrasi yang terdapat pada sampel produk olahan (bakso ikan dan crab stick) menunjukkan nilai konsentrasi DNA yang lebih kecil dibanding dengan konsentrasi DNA pada sampel ikan segar dan steik tuna. Nilai konsentrasi DNA pada sampel bakso ikan dan crab stick masing-masing menunjukkan nilai sebesar 101,95 ng/ $\mu \mathrm{L}$ dan 34,950 ng/ $\mu \mathrm{L}$. Hal ini terjadi karena produk olahan telah mengalami proses pengolahan seperti pemanasan dan penambahan bahan-bahan lainnya. Stevanofa et al. (2013) menjelaskan bahwa proses pengolahan pangan dapat menurunkan tingkat konsentrasi DNA yang diperoleh.

Hasil yang diperoleh pada Table 2 menunjukkan tingkat kemurnian DNA

Table 1 DNA concentration performed by different extraction methods

\begin{tabular}{lrrrrr}
\hline \multirow{2}{*}{ Method } & \multicolumn{5}{c}{ DNA concentration $(\mathrm{ng} / \mu \mathrm{L})$} \\
\cline { 2 - 6 } & Crab stick & Skipjack & Tuna steak & Fishball & Tilapia \\
\hline CTAB & 34.95 & 273.50 & 461.65 & 101.95 & 308.90 \\
Qiagen (Blood and Tissue) & - & 303.20 & 282.70 & - & 193.20 \\
Qiagen (Food) & 82.90 & - & - & 43.15 & - \\
TianGen & 5.50 & 49.50 & 12.35 & 3.15 & 33.65 \\
DNAzol & 62.35 & 62.35 & 75.10 & 92.25 & 81.75 \\
Fasmac & 87.40 & 357.65 & 212.85 & 43.00 & 223.65 \\
\hline
\end{tabular}

Note: (-) Crab stick and fishball processed products are not tested using a Qiagen Blood and Tissue Kit; (-) Fresh fish (Skipjack tuna and Nile tilapia) and tuna steak are not tested using a Qiagen Mericon Food Kit. 
Table 2 DNA purification performed by different extraction methods

\begin{tabular}{lrrrrr}
\hline \multirow{2}{*}{ Method } & \multicolumn{5}{c}{ DNA purification (A260/A280) } \\
\cline { 2 - 6 } & Crab stick & Skipjack & Tuna steak & Fishball & Tilapia \\
\hline CTAB & 1.70 & 1.92 & 1.53 & 1.60 & 1.79 \\
Qiagen (Blood and Tissue) & - & 3.85 & 3.85 & - & 4.19 \\
Qiagen (Food) & 1.76 & - & - & 1.51 & - \\
TianGen & 1.47 & 1.93 & 1.60 & 1.29 & 1.76 \\
DNAzol & 4.97 & 6.21 & 6.21 & 5.93 & 6.29 \\
Fasmac & 1.17 & 2.98 & 3.18 & 1.59 & 3.79 \\
\hline
\end{tabular}

Note: (-) Crab stick and fishball processed products are not tested using a Qiagen Blood and Tissue Kit; (-) Fresh fish (Skipjack tuna and Nile tilapia) and tuna steak are not tested using a Qiagen Mericon Food Kit.

tertinggi dihasilkan oleh metode CTAB kemudian diikuti oleh Qiagen pada sampel produk olahan dan TianGen pada sampel ikan segar. Tingkat kemurnian DNA dikatakan baik jika memiliki rasio 1,6-2,00 (Heptinstall dan Rapley 2000; Wongsawad et al. 2006). Berdasarkan hasil tersebut menunjukkan bahwa isolat DNA yang diisolasi menggunakan metode CTAB (kecuali steik tuna) relatif murni dan terbebas dari kontaminan, begitu pula dengan metode kit The DNeasy Mericon Food (Qiagen) pada sampel crab stick dan metode kit TianGen pada sampel ikan segar (ikan cakalang, nila, dan steik tuna). Tingkat kemurnian DNA yang rendah disebabkan oleh masih tingginya komponen pengotor (protein) yang terukur, diduga pada proses ekstraksi DNA, protein tidak terdegradasi seluruhnya. Kontaminasi yang disebabkan oleh protein dapat berasal dari komponen sel yang tidak lisis selama proses isolasi atau berasal dari fenol sebagai bahan yang ditambahkan pada proses isolasi untuk mempresipitasi DNA (Bellard et al. 1973). Tingkat kemurnian yang rendah juga dapat disebabkan oleh adanya komponen pengotor lainnya, yaitu RNA, lipid, dan polisakarida (Alaey et al. 2005).

\section{KESIMPULAN}

Isolasi DNA menggunakan metode yang berbeda menunjukkan hasil yang berbeda pada tingkat konsentrasi dan kemurnian isolat DNA. Isolat DNA yang diisolasi menggunakan metode konvensional CTAB relatif murni, begitu pula dengan metode kit The DNeasy Mericon Food (Qiagen) pada sampel crab stick dan metode kit TianGen pada sampel steik tuna dan ikan segar (ikan cakalang dan nila). Isolat DNA produk perikanan segar memiliki kandungan konsentrasi DNA yang lebih tinggi dibandingkan dengan isolat DNA pada produk perikanan olahan.

\section{UCAPAN TERIMA KASIH}

Penulis mengucapkan terimakasih kepada Kementerian Riset, Teknologi dan Pendidikan Tinggi yang telah mendanai penelitian ini pada program Insentif Riset Sistem Inovasi Nasional (INSINAS) a.n Dr. Mala Nurilmala, S.Pi., MSi dengan judul Pendeteksi Produk Perikanan dalam Rangka Pengembangan Metode Ketertelusuran (Traceability) sesuai Surat Perjanjian Penugasan Nomor: 1/E1/ KP.PTNBH/2020 dan 2575/IT3.L1/PN/2020, dalam rangka pelaksanaan kegiatan Penelitian Dasar Unggulan Perguruan Tinggi (PDUPT).

\section{DAFTAR PUSTAKA}

Abdullah A, Nurilmala M, Sari S, Jacoeb AM. 2018. Mini-coi barcodes sebagai penanda molekuler untuk ketertelusuran label pangan berbagai produk olahan ikan sidat. Jurnal Pengolahan Hasil Perikanan Indonesia. 21(2): 377-384.

Abdullah A, Sativa HA, Nurhayati T, Nurilmala M. 2019a. Pemanfaatan DNA barcoding untuk ketertelusuran label berbagai produk olahan ikan berbasis surimi komersial. Jurnal Pengolahan Hasil Perikanan Indonesia. 22: 508-519.

Abdullah A, Nurilmala M, Sitaresmi KP. 2019b. DNA mini-barcodes sebagai penanda molekuler untuk ketertelusuran label pangan berbagai produk ikan 
layur. Jurnal Pengolahan Hasil Perikanan Indonesia. 22(1): 33-40.

Alaey M, Naderi R, Verzaei A, Khalighi A, Salami A. 2005. Comparing study between four different methods of genomic DNA extraction from Cyclamen persicum Mill. International Journal of Agriculture and Biology. 7(6): 882-884.

Armani A, Guardone L, La Castellana R, Gianfaldoni D, Guidi A, Castigliego L. 2015. DNA barcoding reveals commercial and health issues in ethnic seafood sold on the Italian market. Food Control. 55: 206-214.

Asche F, Bellemare MF, Roheim C, Smith MD, Tveteras S. 2015. Fair enough? Food security and the international trade of seafood. World Development. 67: 151160.

Bellard MG, Outdet P, Chambon P. 1973. Isolation of high molecular weight DNA from mammalian cells. European Journal of Biochemistry. 36(1): 32-38.

Bohme K, Calo-Mata P, Barros-Velazques J, Ortea I.2019. Review of recentDNA-based methods for main food authentication topics. Journal of Agriculture and Food Chemistry. 67: 3854-3864.

Carvalho DC, Palhares RM, Drummond MG, Frigo TB. 2015. DNA barcoding identification of commercialized seafood in South Brazil: A governmental regulatory forensic program. Food Control. 50: 784-788.

Chen H, Rangasamy M, Tan SY, Wang H, Siegfried BD. 2010. Evaluation of five methods for total DNA extraction from western corn rootworm beetles. PLoS One. 5(8).

Chowdhury MM, Rahman AS MS, Nahar L, Rahman M, Al Reza H, Ahmed MS. 2016. Efficiency of different DNA extraction methods for fish tissues: A comparative analysis. IOSR Journal of Pharmacy \& Biologocal Science. 11(3): 11-15.

Civera T. 2003. Species identification and safety of fish products. Veterinary Research Communications. 27(1): 481-489.

Dhaneesh KV, Noushad KM, Ajith KTT. 2012.
Nutritional evaluation of commercially important fish species of Lakshadweep archipelago, India. PLoS One. 7(9): e45439.

Di Pinto A, Marchetti P, Mottola A, Bozzo G, Bonerba E, Ceci E, Bottaro M, Tantillo G. 2015. Species identification in fish fillet products using DNA barcoding. Journal of Fisheries Research. 170: 9- 13.

Dwiyitno, Hoffman S, Parmentier K, Van Keer C. 2018. Method comparison of DNA isolation and quantification for fish and seafood authenticity determination. Squalen Bulletin of Marine and Fisheries Postharvest and Biotechnology. 13(3):115124.

Fitriya RS, Ibrahim M, Lisdiana L. 2015. Keefektifan metode isolasi DNA kit dan $\mathrm{CTAB} / \mathrm{NaCl}$ yang dimodifikasi pada Staphylococcus aureus dan Shigella dysentriae. LenteraBio. 4(1): 87-92.

Gardenia L, Koesharyani I. 2011. Metode isolasi deoxyribo nucleic acid bakteri dari organ ikan nila (Oreochromis niloticus) untuk diagnosa Streptococcociasis dengan teknik Polymerase Chain Reaction. Jurnal Riset Akuakultur. 6(3): 469-477.

Hajibbaei M, Smith MA, Janzen DH, Rodriguez JJ, Whitfield JB, Hebert PDN. 2006. A minimalist barcode can identify a specimen whose DNA is degraded. Molecular Ecology Notes. 6(4): 959-964.

Harahap MR. 2018. Elektroforesis: Analisis elektronika terhadap biokimia genetika. Jurnal Ilmiah Pendidikan Teknik Elektro. 2(1): 21-26.

Hartati D, Anto K, Taryono, Endang S, Widyatmoko A. 2007. Pendugaan keragaman genetik di dalam dan antar provenan pulai (Alstonia scholaris (L.) R. Br.) menggunakan penanda RAPD. Jurnal Pemuliaan Tanaman Hutan. 1(2): 1-8.

Hebert PDN, Cywinska A, Ball SL. 2003. Biological identification through DNA barcodes. Proceedings of the Royal Society of London. 270: 313-321.

Heptinstall J, Rapley R. 2000. The Nucleic Acid 
Protocold Handbook. Totowa NJ: Humana Press Inc.

Hu Q, Liu Y, YiS, Huang D. 2015. A comparison of four methods for PCR inhibitor removal. Forensic Science International: Genetics. 16: 94-97.

Khaksar R, Carlson T, Schaffner DW, Ghorashi M, Best D, Jandhyala S. 2015. Unmasking seafood mislabeling in U.S. markets: DNA barcoding as a uniq technology for food authentication and quality control. Food Control. 56(1): 71-76.

Lai Y, Deepali S, Norman A, Fengzhu S. 2003. The mutation process of microsatellites during the polimerase chain reaction. Journal of Computational Biology. 10(2): 143-155

Lamendin R, Miller K, Ward RD. 2015. Labelling accuracy in Tasmanian seafood: An investigation using DNA barcoding. Food Control. 47(1): 436-443.

Lee JH, Park Y, Choi JR, Lee EK, Kim HS. 2010. Comparisons of three automated systems for genomic DNA extraction in a clinical diagnostic laboratory. Yonsei Medical Journal. 51(1): 104-110.

Lin Y, Yanhua J, Qingjiao L, Zhe S, Lianzhu W, Yuxiu Z. 2016. A comparison of eight methods for DNA etraction from processed seafood products. Food Science and Technology Research. 22 (6): 751-757.

Mackie IM, Pryde SE, Sotelo GC, Medina I, Martin IR, Quinteiro J, ReyMendez M, Rehbein H. 1999. Challenges in the identification of species of canned fish. Trend and Food Science and Technology. 10(1): 9-14.

Maulid YD, Nurilmala M. 2015. DNA Barcoding untuk Autentikasi Produk Ikan Tenggiri (Scomberomorus sp.) DNA. Jurnal Akuatika. 4: 154-160.

Maulid DY, Nurilmala M, Nurjanah, Maddupa H. 2016. Karakteristik molekuler cytochrome b untuk DNA barcoding ikan tenggiri. Jurnal Pengolahan Hasil Perikanan Indonesia. 19(1): 9-16.

Meusnier I, Singer GAC, Landry JF, Hickey DA, Hebert PDN, Hajibabaei M. 2008. A universal DNA mini-barcode for biodiversity analysis. BMC Genomics. 9: 214.

Milana V, Fusari A, Rossi AR, Sola L. 2011. Molecular and morphological identification of an uncommon centrolophid fish. Central European Journal of Biology. 6(3): 440-445.

Muhammad H, Iqbal Z, Iqbal MU, Younas T, Bashir Q. 2016. An efficient method for DNA isolation from fish fin. Pakistan Journal of Agriculture Sciences. 53(4): 843-850.

Naaum AM, Warner K, Mariani S, Hanner RH, Carolin CD. 2016. Seafood mislabeling incidence and impacts. In A. Naaum, \& R. Hanner (Eds.). Seafood mislabeling incidence and impacts seafood authenticity and traceability. San Diego (US): Academic Press.

Nichols PD, Glencross B, Petrie JR, Singh SP. 2014. Readily available sources of longchain omega-3 oils: is farmed Australian seafood a better source of the good oil than wild-caught seafood?. Nutrients. 6(3): 1063-1079.

Rasmussen-Hellberg RS, Naaum AM, Handy SM, Hanner RH, Deeds JR, Yancy HF, Morrisey MT. 2011. Interlaboratory evaluation of a real-time multiplex polymerase chain reaction method for identification of salmon and trout species in commercial products. Journal of Agricultural and Food Chemistry. 59(3): 876-884.

Sambrook J, Russel DW. 2001. Molecular Cloning: A Laboratory Manual. Edisi ke3. New York (US): Cold Spring Harbor Laboratory Press.

Shokralla S, Zhou X, Janzen DH, Hallwachs W, Landry JF, Jacobus LM, Hajibabaei M. 2011. Pyrosequencing for mini-barcoding of fresh and old museum specimens. PLoS ONE. 6(7).

Stevanofa P, Taseva M, Georgieva T, Gotcheva V, Angelov A. 2013. A modified CTAB method for DNA extraction from soybean and meat products. Biotechnology \& Biotechnological Equipment. 27(3): 3803-3810. 
Suparningtyas JF, Pramudyawardhani OD, Purwoko D, Tajuddin T. 2018. Analisis filogenetik beberapa klon karet dengan marka AFLP (Amplified Fragment Length Polymorphism). Jurnal Bioteknologi \& Biosains Indonesia. 5(1): 8-19.

Wasko AP, Martins C, Oliveira C, Foresti F. 2003. Non-destructive genetic sampling in fish. An improved method for DNA extraction from fish fins and scales. Hereditas. 138:161-165.

Westermeier. 2004. Electrophoresis in Practice: A Guide to Theory and Practice. New Jersey (US): John Wiley \& Sons Inc.
Wong EHK, Hanner RH. 2008. DNA barcoding detects market substitution in North American seafood. Food Research International. 41(8): 828-837.

Wongsawad C, Wongsawad P, Chai JY, Paratapsilpin T, Anuntalabhochai S. 2006. DNA quantities and qualities from various stages of some trematodes using optical and hat-RAPD methods. Southeast Asian Journal Tropical Medicines Public Health. 37(3): 62-68.

Zhang J, Hanner R. 2012. Molecular approach to the identification of fish in the South China Sea. PLoSONE. 7(2) : e306211 